\title{
The Relationship between Environmental Education and Tourist Activity in Accordance with the Brazilian Laws
}

\author{
By Luciana Correia Diettrich* \\ Ademir Kleber Morbeck de Oliveira \\ Daniela Sottili Garcia ${ }^{\dagger}$
}

If on the one hand, the current Brazilian scenario, in case of its natural resources, is composed by an undeniable wealth; on the other hand, this same wealth is under severe threat, for various reasons. The country's natural aspects are expressive potential or tourist attractive activities already consolidated. The balance of the environment is considered a right of Brazilian citizens, guaranteed by their law, which also establishes environmental education as a tool for preservation. Tourism directly interferes in the environment in a negative way and/or positively. Thus, this study aims to relate the tourist activity with the environmental education from the perspective of laws 6.938/81, 9.795/99 and 11.771/2008, which shall deliberate on the National Policy on the Environment, Environmental Education and the National Policy for tourism, respectively. Soon, we observed that, although such laws provide for environmental education clearly as principle, as a national policy or even as objectives determined, the relationship with the tourism is especially when it comes to tourism in natural areas and ecotourism. Considers, therefore, that the noninvolvement, by laws studied, other segments, services and products of this sector, can contribute to the reduction of the protection of the environment and compliance with laws.

Keywords: Environment, laws, tourism, environmental education.

\section{Introduction}

Environmental problems have intensified for the last decades and the crisis which plagues planet Earth is now a fact. However, it is possible to recognise alternatives which aim to the solution or attenuation of such problems. The survival of living beings depends on the environment. Human actions and activities, including the ones stemming from tourism, hit the environment and may impact it negatively, but also positively.

If, on the one hand, the interference of touristic activity, through the movement of people, the deployment of services and products, the modification of landscapes and local cultures, has great potential for the degradation of the natural and/or historical-cultural heritage, on the other hand,

\footnotetext{
* Doctoral Student in Environment and Regional Development, Anhanguera-Uniderp University and Assistant Professor, Federal University of Mato Grosso do Sul, Brazil.

* Professor, Anhanguera-Uniderp University, Brazil.

${ }^{\dagger}$ Professor, State University of Mato Grosso do Sul - College Unity of Campo Grande, Brazil.
} 
people's approximation and direct and dynamic interaction with several and different environments, provided by tourism, give them the condition to promote its conservation, once the experience acquired during the trips often sensitize travellers.

Among the existing alternatives for the promotion and conservation of the environment, there is the environmental education as a way to make people aware of the vital importance of all the elements encompassed by it and, so, to transform such awareness into everyday practice.

A conserved environment is, according to the Brazilian legislation, a right and also a duty of the citizens, and environmental education, an essential and permanent component of the national education, must be present and articulated in all levels and modalities of the educational process.

That being said, this paper intends to emerge the topics: environment, environmental education and touristic activity, through the eyes of the Brazilian legislation, bounding to the Laws 6.931 of 1981, 9.795 of 1999, and 11.771 of 2008 , in order to reflect on the relation among the referred themes and on the role of tourism when dealing with the needs of environmental conservation and of the enforcement of national laws.

\section{Literature Review}

An ecologically balanced environment is everyone's right, as well as its preservation is a duty of the Public Power and of the society, which must defend it and preserve it, because it is fundamental, not only to the quality of life, but also to its existence. Such rights and duties, in Brazil, are stablished and protected by the Federal Constitution (Brasil, 2011, Article 225).

The same legislation considers the environment as a common use asset of the people and, still under that perspective, stablishes duties for the Public Power and obligations for individuals and legal entities, besides (penal and administrative) sanctions for any environmentally harmful activities and conducts.

It is known that the current conception of environment understands the term broadly, constituted both by natural, artificial, and cultural elements and the interaction among them. Therefore, by the legal definition stablished through the Law 6.931/81, which rules on the National Environmental Policy, it is possible to observe that such complexity is comprehended by the Brazilian legislation. The law conceptualizes environment as '[...] the set of conditions, laws, influences, and interactions of physical, chemical, biological, social, cultural, and urbanistic order, which allows, shelters, and rules life in all its forms'.

In the theoretical field, observing the examples of what environment encompasses, Silva (2004) organizes it under four aspects: the natural or physical environment (constituted by the soil, water, atmospheric air, flora, and others) and the relation among the species and the environment they inhabit, the artificial environment (built urban space), the cultural environment 
(historical, artistic, archaeological, landscape, and touristic patrimony), and the work environment (set of several factors which influence the work space).

Among the several mechanisms which are possible and aimed to the conservation of the environment, environmental education is a significant way to obtain balance and reasoning concerning the consumption and preservation of a location's natural, social, cultural, and economic resources (Cirilo, 2005). So, the Brazilian Federal Constitution imposes the Public Power the duty to promote an environmental education in all levels of education and a public awareness for the preservation of the environment (Brasil, 2011, Article 225).

The Law 9.975, of April 1999, which rules on the National Environmental Policy, in its Article 1, conceptualizes environmental education as

[...] the processes through which an individual and the society build social values, knowledge, abilities, and competences aimed to the conservation of the environment, a common use asset of the people, essential to a healthy quality of life and its sustainability (Brasil, 2002).

Concerning what is proposed by environmental education, it is necessary to adopt conducts which make individuals think critically and reflexively, to understand that their existence depends on the protection of the environment where they live. Ruschmann (1997, p.74) points out that '[...] the key to the change of the agents' behaviour lies on spreading new knowledge and ideas through education.'

It is important to highlight that what is learnt from environmental education must move from the field of reflection onto everyday practice, i.e., to be taken to everyday life situations (Quintas, 2000).

In line with what the Federal Constitution rules and with human needs, tourism shows itself fearful when facing the consequences which the environment suffers from economic activities and, particularly, the degradation of resources and for the degree of irreversibility. For the World Tourism Organization - UNWTO, tourism has a significant role to play regarding a sustainable development and, if well managed, it may benefit local communities and the natural and cultural environments it depends on. Recognising the potential presented by tourism, the United Nations declare the year 2017 as the International Year of Sustainable Tourism for Development (UNWTO, 2013; 2015).

Although there are many definitions of tourism, it is possible to recognise that it is about an activity which involves the economic, social, cultural, and political aspects, which interfere, promote, and make the contact of people with different environments and their elements possible, being described as:

[...] the set of results of economic, financial, political, social, and cultural nature, produced in a location, stemming from the temporary presence of people who move from their habitual living location to others, spontaneously and with non-profit objectives (Oliveira, 2000, p.32). 
However, the concept of tourism proposed by the Federal Constitution emphasizes the activities which are performed during a trip, the destination's stay time and objectives. According to the Article 2 of the Law no. 11.771, of 17 September 2008, '[...] it is considered tourism activities performed by individuals during trips and stays in locations other than their habitual surroundings, for a period shorter than 1 (one) year, with leisure, business or other objectives.' The same law, then, shows that a preserved environment is part of the attributions of the touristic activity. According to Article 2,

The trips and stays which this article's caput deals with must create economic movement, work, employment, income, and public revenues, constituting instrument of economic and social development, cultural promotion and diversity, and preservation of the biodiversity.

For Oliveira (2008), the relation between tourism and environment is fairly complex, involving several activities which may have many adverse environmental effects; however, the activity also presents potential to contribute to environmental conservation.

Understanding tourism as a way of development and growth, it is possible to see the need for involving the issue of environmental sustainability, since the (social, cultural, economic, and/or natural) impacts caused by touristic activities are inevitable. Mendonça (2001), regarding the touristic activity and a sustainable development, highlights two sides: if, on the one hand, tourism enables negative impacts on the hosting locations under the most diverse circumstances, on the other hand, it is capable of providing a direct contact and a greater knowledge, which generates a better quality of perception of the local environmental characteristics.

The Ministry of Tourism (Brasil, 2007), in turn, warns that mistakenly, sometimes, it is suggested that sustainable tourism be only another type of tourism, synonym of ecotourism and opposite of mass tourism. But the concept of sustainable development must be applied to any segments of tourism and at any scales, from mass tourism and its large resorts to the one developed in small scale and in environmentally fragile locations, of unique ecosystems and preserved nature.

Recognizing that tourism is a complex activity, which involves different areas, agencies, and stages, it is understood that it has many opportunities to evoke educational actions aiming to the conservation of the environment in all its aspects: in the scope of touristic operators, elaborating itineraries ecologically adjusted to the practices of environmental protection; through the Public Power, taking part in the promotion of responsible environmental tourism, and through parks, providing recreational playful activities, environmentally educating and sensitizing visitors. Tour guides, adopting the role of environmental educators, may orient visitors, making them reflect on the need for respect for the environment and encouraging them to adopt sustainable practises. (Ruschmann, 1997; Oliveira and Irving, 2010; Azevedo, 2014). 
In that sense, it is possible to infer that tourism has the capacity to serve as an instrument for environmental education and, therefore, corroborate the sustainability of the environment it depends on to exist, i.e., to favour a sustainable development.

Regarding environmental education through touristic activity, when focused on the community, it must aim to the development of a critical and questioning conduct, besides the ability to propose solutions to problems and, so, to be effectively involved in the touristic process (Cirilo, 2005). It is important that tourists are led to '[...] an aware participation in the protection of the environment not only during their holidays, but also in their everyday lives, in their permanent living residence' (Ruschmann, 1997, p.75).

Under that perspective, tourism, because of its characteristics and through its practises, may arrogate environmental education, making the need for a sustainable and responsible use of the environment apparent (Beni, 2002).

\section{Methodology}

This research is defined as exploratory (Dencker, 1998) and aimed to evoke the relation between environmental education and touristic activity through the eyes of the Brazilian legislation. For that, bibliographic and documentary methodologies were used. As documentary research, the collecting source is associated to written documents, named as primary sources, which are collected after the phenomenon has happened (Marconi and Lakatos, 2006).

Therefore, the researched sources were available studies and previously performed ones, besides the following Laws: Law no. 6.938, of 31 August 1981, which rules on the National Environmental Policy, its goals, and formulation and enforcement mechanisms; Law no. 9.975, of 27 april 1999, which rules on environmental education and implements the National Environmental Education Policy; and Law no. 11.771, of 17 september 2008, which decides on the National Tourism Policy, defines the Federal Government's planning attributions, development, and stimulation to the tourism sector, and gives other measures.

\section{The Correlations between Environmental Education and Tourism through the Eyes of the Brazilian Laws}

Considering the complexity of the term and aspects involved by the environment, several Brazilian laws directly and/or indirectly rule on the related conducts. Regarding the legislation on tourism, although the 1988's Federal Constitution (Brazil's highest law) was the first one to adopt tourism in general (Art. 180, chapter on the General Principles of Economic Activities), a few others deal with and rule on that activity in the country. 
For this paper, the Laws 6.938 of 1981, 9.795 of 1999, and 11.771 of 2008 were selected.

\section{On the National Environmental Policy}

The Law 6.938 of 1981 rules on the National Environmental Policy, its goals, and formulation and enforcement mechanisms, constitutes the National Environmental System (SISNAMA) and institutes the Environmental Defence Register.

The way it is presented today, it is the result of different undergone changes which, through several laws, changed, revoked, vetoed, and/or added articles, items, and paragraphs in it.

According to what has the law, the scope is the preservation, the improvement, and the recovery of the environmental quality in order to assure conditions for the socioeconomic development, for the interests of the national security, and for the protection of the dignity of human life in Brazil.

For that purpose, the mentioned law determines ten principles to be followed - one clearly referring to environmental education in the following way: 'environmental education for all levels of education, including community education, aiming to enable it for an active participation in the defence of the environment' (Art. 2, X).

Seven objectives compose the law on the National Environmental Policy, which, in summary, involve: the balance, preservation, and recovery of the environment; governmental actions; establishment of criteria, standards, and regulations; support for research and technologies; obligations and formation of public awareness which corroborate the environmental quality, compatible economic development.

The Law 6.938/81 even stablishes that governmental actions as well as entrepreneurial activities must be oriented as to conform to it.

Concerning the SISNAMA, the mentioned law decides on its constitution and structure which the Union, the States, the Federal District, the Territories, the Municipalities, and the Foundations instituted by the Public Power are part of and are responsible for the protection and improvement of the quality of the environment, which must happen, in summary, through policies, directives, regulations and standards, supervision, activities, programs, and projects, besides control and promotion of the environmental resources distributed to competent agencies.

The referred law also rules on the National Environmental Board (CONAMA) regarding its competencies which, briefly, relate to: the establishment of rules and criteria for the licencing of polluting activities, the determination of studies on alternatives and projects' environmental consequences, the determination of loss or restriction of tax benefits and of participation in financing lines in official credit establishments, establishment of rules and standards of automotive vehicles, aircraft, and vessels pollution control, besides the establishment of rules, criteria, and standards related to the 
control and maintenance of the environmental quality aiming to the rational use of environmental resources.

Among the instruments of the National Environmental Policy, it is highlighted here the ones which are the closest to the touristic activity, namely: the licencing and review of effectively or potentially polluting activities (item IV), the creation of territorial spaces specially protected by the Public Power [...], such as areas of environmental protection, of relevant ecological interest, and reserves (item VI), and the Federal Technical Register of potentially polluting activities and/or which use environmental resources (item XII).

It is observed that, according to the mentioned instruments, tourism is reached by the Law 6,938 once it is often configured as an activity, that environmentally protected spaces are touristic attractions, and that the natural resources are potentialities increasingly exploited by tourism.

It is important to make clear that, in a document enclosed to the mentioned law, tourism is a part of the potentially polluting activities and which uses environmental resources, being referred to through touristic and leisure complexes and theme parks.

Another correlation which there is among the themes proposed here under the eyes of the Law 6,938 happens through its Article 13, which stablishes that the Executive Power will encourage activities related to the environment aiming to initiatives which provide the rationalization of the use of environmental resources. Under that perspective, it is observed that the environmental education meets the stablished proposal and that touristic activities are possible ways to reach such purpose.

As to the Federal Technical Register of environmental defence activities and instruments and of potentially polluting activities or which use environmental resources, the law decides that the register is mandatory for individuals and legal entities, and the administration of such register is a duty of the Brazilian Institute of Environment and Renewable Natural Resources (IBAMA). The IBAMA is also responsible for ecological stations and reserves.

Evidently, the law studied here focuses on the preservation and/or conservation of the environment in all its aspects and, therefore, tries to endorse actions which corroborate its effectiveness. However, clearly, it recognises environmental education as an instrument for environmental sustainability.

Yet it is possible to notice a reference to the touristic activity as it often is configured as a business and it involves different activities. Under that perspective, it is up to tourism to be in conformity to the referred law and to be a mechanism aiming to the quality of the environment.

\section{On the Environmental Education Policy}

The Law 9.795 of 1999 rules on environmental education, institutes the National Environmental Policy and provides other measures.

According to that law, "environmental education is an essential and permanent component of the national education, and it must be present, in an 
articulate way, in all levels and modalities of the educational process, in formal and informal character ${ }^{1}$ (Art. 2) and, being part of a broader educational process, environmental education is everyone's right.

As for tourism, it is important to remember that many professionals of the area are formally prepared to act in it and an environmental education in the scope of graduation provides the sector with environmental awareness and knowledge.

So, the Law 9.795/99 involves and delegates to the Public Power the definition of public policies on the promotion of environmental education and on the society's engagement; to educational institutions, the environmental integration to the educational programs; to member agencies of the SISNAMA, the promotion of environmental education actions; to the means of mass communication, the collaboration on the spread of information and educational practices about the environment and the inclusion of the environmental dimension in its programming; to businesses, class entities, and public and private institutions, the promotion of programs focusing on the qualification of workers regarding the improvement and control over the work environment; and to society as a whole, the attention to the formation of values, attitudes, and abilities focused on the preservation, identification, and solution of environmental problems.

Considering the objective of this paper, it is important to highlight the basic principles of environmental education determined in the Art. 4 of the referred law, which are:

I. the humanistic, holistic, democratic, and participative focus;

II. the conception of the environment in its totality, considering the interdependence among the cultural, socioeconomic, and natural environment, under the focus of sustainability;

III. the multitude of pedagogical conceptions and ideas, under the perspective of inter, multi, and transdisciplinarity;

IV. the ties among ethics, education, labour, and social practices;

V. the guarantee of the continuity and permanence of the educational process;

VI. the permanent critical evaluation of the educational process;

VII. the articulated approach of local, regional, national, and global environmental issues;

VIII. the recognition of and respect for individual and cultural diversity and plurality.

Here, it is possible to observe points converging with touristic activity, once it involves and is involved with the different aspects of the environment

\footnotetext{
${ }^{1}$ Environmental education in formal education is the one which happens in school education, developed in the scope of the syllabus of private and public educational institutions; and informal environmental education relates to the educational practices and actions focused on the sensitization of the collectivity about environmental issues and on its organization and participation on the defence of the quality of the environment (Brasil, 2002).
} 
and glimpses (at least theoretically) at a sustainable development. In that sense, the principles of environmental education consolidate a responsible tourism.

As for the objectives defined by the Law 9.795/99 for environmental education, they involve: the development of an integrated understanding about the environment in its multiple and complex relations; the guarantee of the democratization of environmental information; the stimulation and strengthening of a critical awareness about social and environmental issues; the incentive to a permanent and responsible, collective and individual participation in the preservation of the environmental balance; the stimulus to cooperation among the several regions of the country aiming to build an environmentally balanced society; the promotion and strengthening of the integration with science and technology and the strengthening of citizenship, people's self-determination, and solidarity as foundations for the future of mankind.

Conforming to the related objectives, it is possible to understand that tourism finds itself prone to fulfil them, mainly the ones explained in the Article 5 (IV and VII), which respectively stablishes:

IV - the incentive to a permanent and responsible, collective and individual participation in the preservation of the environmental balance, extending to the defence of the quality of the environment as a value inseparable from the exercise of citizenship;

VII - the strengthening of citizenship, people's self-determination, and solidarity as foundations for the future of mankind.

The National Environmental Policy involves agencies and member entities of the SISNAMA, public and private educational institutions, public agencies of the Union, of the States, of the Federal District, and of the Municipalities, and non-governmental organizations acting on environmental education.

According to the referred Policy, the activities related to it extend to education in general and to school education, which must be based on the following lines of actuation: human resources qualification; development of studies, researches and experiments; production and diffusion of educational material, monitoring, and evaluation (Art. 8).

Regarding informal environmental education, it is up to the Public Power (in municipal, state and federal levels) to encourage the diffusion of educational campaigns and programs and of information about topics related to the environment; to promote a wide participation of the school, of the university and of non-governmental organizations in the formulation and execution of programs and activities; to provide the participation of public and private businesses in partnership with the school, with the university and with non-governmental organizations in the development of programs; to environmentally sensitize society in relation to the conservation units; to environmentally sensitize agriculturists and to encourage ecotourism. 
Taking the law into account, the actions of tourism (as well as of other areas) may have better results if they happen in partnership with the Public Power since it is up to the latter to support healthy initiatives.

The Law 9.795 of 1999 rules that the coordination of the National Environmental Policy is a duty of a managing agency ${ }^{2}$ which must be responsible for the definition of directives, for the articulation, coordination, and supervision of plans, programs, and projects, and for the participation in the negotiation of the financing of plans, programs, and projects in the area of environmental education. However, the States, the Federal District, and the Municipalities, in the sphere of their competence and in the areas of their jurisdiction, will define directives, regulations, and criteria for environmental education, respecting the principles and objectives of the National Environmental Policy.

That law also regulates the criteria for the allocation of public resources linked to the National Environmental Policy.

In a more comprehensive way and regarding the touristic activity potential for environmental education, Hillel (1999, p.57) declares that 'travelling has always been one of the most efficient, enjoyable and complete ways of education.'

\section{On the National Tourism Policy}

Finally, the Law no. 11.771, of 17 september 2008, stablishes regulations for the National Tourism Policy, defines the duties of the Federal Government on the planning, development, and stimulation to the touristic sector, and disciplines the provision of touristic services, the registering, classification, and supervision of touristic services providers.

By the law mentioned above, the Ministry of Tourism is responsible for stablishing the National Tourism Policy, for planning, regulating, coordinating, and supervising the touristic activity, besides institutionally promoting and diffusing tourism.

By that means, the articulation among tourism and environment and sustainability happens daily, since the law accentuates that sustainability must be advocated by the touristic activity. Therefore, environmental education becomes an important way to fulfil it. According to the Article 3,

The Public Power will act, through technical, logistic, and financial support, on the consolidation of tourism as an important factor of sustainable development, of income distribution, of employment generation, and of conservation of the Brazilian natural, cultural, and touristic patrimony.

Still focusing on sustainability, the same law indicates that tourism must promote the protection of the environment, of the biodiversity, and of the

\footnotetext{
${ }^{2}$ The Managing Agency of the National Environmental Education Policy (PNEA) consists of the Ministries of Environment and of Education and was instituted in June 2003.
} 
cultural patrimony of touristic interest, as well as stimulate responsible tourism practised in natural areas, protected or not.

The constitutional principles which rule the policy are the ones of free initiative, of decentralization, of regionalization, and of fair and sustainable socioeconomic development.

There are twenty objectives defined for the National Tourism Policy, which refer to: the access to tourism in the country, reduction of social and economic inequalities; expansion of touristic flows, of permanence, and of tourists' average expenditure in the country; creation, consolidation, and diffusion of touristic Brazilian goods and destinations; support to the accomplishment of events; promotion, decentralization, and regionalization of tourism; creation and implementation of attractive enterprises; preservation of the cultural identity; prevention of and combat to abuses which affect the human dignity; development, ordination, and promotion of several touristic segments; implementation and updating of the national touristic patrimony inventory; provision of resources necessary for investments and use of the national touristic space; increase and diversification of lines of financing for touristic enterprises; promotion of the competitiveness of the sector; establishment of safety, efficiency, and quality regulations and standards; promotion of the qualification of human resources and of the implementation of policies focused on professional placement in the labour market; implementation of production, systematization and interchange of statistical data, and of information related to touristic enterprises and activities installed in the country, among others, highlighting the following objective:

To provide the practice of sustainable tourism in natural areas, promoting the activity as an educational and environmental interpretation means, and encouraging the adoption of minimum practices and conducts compatible with the conservation of the natural environment (Art. 5).

It is important to observe, specifically regarding environmental education, that the Article 5 of the Law 11.771/2008 expresses a relation only with the tourism developed in natural areas and with the conservation of the natural environment.

However, that law is ruled by the National Tourism Policy (PNT) and, therefore, it is up to it to fulfil it. Three objectives of the PNT are highlighted here:

VI - the protection of the environment, of the biodiversity, and of the cultural patrimony of touristic interest;

VII - the attenuation of socioenvironmental assets occasionally caused by touristic activity;

VIII - the stimulation to responsible tourism practised in natural areas, protected or not 
The Law 11.771 of 2008 also rules on travel agencies, touristic transportation agencies, event organization agencies, theme parks, and touristic campsites in relation to their definitions, functions, and rights, not relating any of those issues to environmental responsibility, or environmental education.

As for the duties of touristic service providers, among others it is the one to 'keep, while performing their activities, strict compliance to consumer rights and to the environmental legislation' (Art. 34).

Lastly, the law encompasses the method of supervision, defines infringements and penalties.

\section{Conclusions}

The proposal of this study and the data presented here make it possible to advance in some considerations. It was noticed that the relation questioned here (between environmental education and tourism) has been built, and advancements can already be noticed. Considering the first understanding about tourism by the Federal Constitution in 1988, which attests: 'The Union, the States, the Federal District, and the Municipalities will promote and encourage tourism as a factor of economic and social development' (Art. 180), it is possible to notice that there was an absence of responsibility of the touristic sector regarding sustainability.

However, at this time, the law ruling on the National Environmental Policy has already shown that tourism comprehends potential for the preservation of the environment. Later, the laws ruling the Environmental Education Policy and the National Tourism Policy strengthened, legally, the link among environment, education, and tourism.

The convergences among the studied laws, often times, are not revealed clearly or directly, but it is possible to consider them, since all of them glimpse at and are interested in a preserved environment (Table 1).

It is to be highlighted, however, that the correlation happens mainly when dealing with tourism in natural areas and/or with the typologies related to nature (such as ecotourism or nature tourism).

That emphasis is worrying as long as it promotes a certain connotation of exemption of responsibility of the other segments of tourism towards the environment and its sustainability.

It is important to remember that, independently from the touristic segment and from the location where the activity is being developed, the environment (including the natural one) will suffer the (negative or positive) impacts, directly or indirectly. Therefore, it depends on the ecotourism, spelunking tourism, fishing tourism, adventure tourism, among others, as well as on the historical tourism, shopping tourism, event tourism, etc., to fulfil its role of knowledge multiplier and, thus, to be effectively related to the environmental education. 
Table 1. Correlation between Environmental Education and Touristic Activity, according to the laws 6,938 of 1981, 9,795 of 1999, and 11,771 of 2008

\begin{tabular}{|c|c|c|}
\hline LAW & WHAT THE LAW SAYS & THE CORRELATION(S) \\
\hline \multirow{3}{*}{$\begin{array}{l}6.938 \text { of } 1981 \\
\text { NATIONAL } \\
\text { ENVIRONMENTAL } \\
\text { POLICY }\end{array}$} & $\begin{array}{l}\text { Environmental education to } \\
\text { all levels of education, } \\
\text { including } \\
\text { education }[. . .]\end{array}$ & $\begin{array}{l}\text { Environmental education } \\
\text { makes the touristic sector } \\
\text { instrumental. } \\
\text { Tourism as an } \\
\text { environmental education } \\
\text { mechanism for the } \\
\text { community. }\end{array}$ \\
\hline & $\begin{array}{l}\text { Aims to: } \\
\text { - the balance, the } \\
\text { preservation, and the } \\
\text { restoration of the } \\
\text { environment; } \\
\text { - the creation of public } \\
\text { awareness } \\
\text { corroborates } \\
\text { environmental quality }\end{array}$ & $\begin{array}{l}\text { Environmental education } \\
\text { through touristic activity as } \\
\text { a way to meet those goals. }\end{array}$ \\
\hline & $\begin{array}{l}\text { Activities related to the } \\
\text { environment aiming to the } \\
\text { rationalization of the use of } \\
\text { environmental resources will } \\
\text { be encouraged by the } \\
\text { Executive Power. }\end{array}$ & $\begin{array}{l}\text { Convergence to the } \\
\text { objectives of environmental } \\
\text { education and of tourism. } \\
\text { Tourism as one of the } \\
\text { activities to be encouraged. }\end{array}$ \\
\hline \multirow{3}{*}{$\begin{array}{l}9.795 \text { of } 1999 \\
\text { ENVIRONMENTAL } \\
\text { EDUCATION } \\
\text { POLICY }\end{array}$} & $\begin{array}{l}\text { Environmental education is a } \\
\text { component of the national } \\
\text { education in all levels and } \\
\text { modalities of the educational } \\
\text { process. }\end{array}$ & $\begin{array}{l}\text { Environmental education } \\
\text { makes the touristic sector } \\
\text { instrumental. }\end{array}$ \\
\hline & $\begin{array}{l}\text { Among its principles, are: } \\
\text { - the humanistic, holistic, } \\
\text { democratic, and participative } \\
\text { focus; } \\
\text { - the awareness and the } \\
\text { respect to the plurality and to } \\
\text { the cultural and individual } \\
\text { diversity. }\end{array}$ & $\begin{array}{l}\text { Those principles solidify a } \\
\text { responsible tourism } \\
\text { glimpsed by the activity. }\end{array}$ \\
\hline & $\begin{array}{l}- \text { incentive to the } \\
\text { participation in the } \\
\text { preservation of the } \\
\text { environmental balance [...] } \\
\text { as a value which is } \\
\text { inseparable from the exercise } \\
\text { of citizenship; } \\
-[\ldots] \text { citizenship, self- } \\
\text { determination of peoples, } \\
\text { and solidarity as foundations } \\
\text { for the future of mankind. }\end{array}$ & $\begin{array}{l}\text { Tourism presents itself } \\
\text { conductive to meet them. }\end{array}$ \\
\hline
\end{tabular}




\begin{tabular}{|c|c|c|}
\hline & $\begin{array}{l}\text { It is the public power's } \\
\text { responsibility to } \\
\text { environmentally sensitise the } \\
\text { society regarding the } \\
\text { conservation units and to } \\
\text { encourage ecotourism. }\end{array}$ & $\begin{array}{l}\text { Conservation units are } \\
\text { important touristic areas. } \\
\text { Ecotourism as a form of } \\
\text { environmental education. }\end{array}$ \\
\hline \multirow[t]{2}{*}{$\begin{array}{c}11.771 \text { of } 2008 \\
\text { NATIONAL } \\
\text { TOURISM POLICY }\end{array}$} & $\begin{array}{l}\text { Sustainability must be } \\
\text { professed by the touristic } \\
\text { activity. } \\
\text { Tourism must promote the } \\
\text { protection of the } \\
\text { environment, of the } \\
\text { biodiversity, of the cultural } \\
\text { patrimony of touristic } \\
\text { interest, as well as stimulate } \\
\text { responsible tourism practised } \\
\text { in natural areas, protected or } \\
\text { not. }\end{array}$ & $\begin{array}{l}\text { Tourism and environmental } \\
\text { education become a two- } \\
\text { way street. }\end{array}$ \\
\hline & $\begin{array}{l}\text { Aims to provide the practice } \\
\text { of sustainable tourism in } \\
\text { natural areas, promoting the } \\
\text { activity as a means for the } \\
\text { environmental interpretation } \\
\text { and education, and } \\
\text { encouraging the adoption of } \\
\text { minimum impact practices } \\
\text { and conducts compatible } \\
\text { with the conservation of the } \\
\text { natural environment. }\end{array}$ & $\begin{array}{l}\text { Clear correlation with } \\
\text { environmental education. } \\
\text { Relation with tourism in } \\
\text { natural areas and the } \\
\text { conservation of those } \\
\text { environments. }\end{array}$ \\
\hline
\end{tabular}

Focusing on sustainability, it is visible that environmental education may and must be incorporated to pertinent actions and to the execution of tourism as an instrument to understand local environmental processes and, consequently, its appreciation and defence. It is outlined, in that sense, that that type of education must contemplate both the local community and the tourist. For Azevedo (2014, p. 78), the stimulation to preserve the environment through tourism

[...] is possible to be achieved through the adoption of environmental education conforming to the touristic practices, once, through it, an individual obtains knowledge of the reality, reconstructs their view of the world, and begins to see themselves as the only agent able to promote the desired transformation in several scopes, including the environmental field.

So, it is inferred that every area, element, and/or segment of tourism, through its practices, has the potential, responsibility, and conditions for an 
environmental education and for the protection of the environment and, consequently, for the compliance with the national laws, which may and must happen in several moments, in different ways, through its many promoting agents.

On the other hand, it is also possible to understand that the legislation contributes for the balance of the environment.

\section{Acknowledgments}

Our thanks to Foundation to Support the Development of Education, Science and Technology of the State of Mato Grosso do Sul - FUNDECT and to Higher Education Personnel Improvement Coordination - CAPES by doctoral scholarship.

\section{References}

Azevedo, A. S. C. 2014. A educação ambiental no turismo como ferramenta para a conservação ambiental. AOS - Amazônia, Organizações e Sustentabilidade. V. 3, n.1, jan./jun. p. 77-86.

Beni, M. C. 2002. Análise estrutural do turismo. 7. ed. São Paulo: Senac.

BRASIL. 2011. Constituição (1988). Constituição da República Federativa do Brasil. Brasília: Senado Federal.

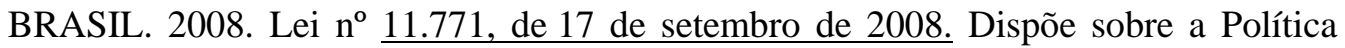
Nacional de Turismo, define as atribuições do Governo Federal no planejamento, desenvolvimento e estímulo ao setor turístico. Diário Oficial da União. Brasília, DF, 18 set. 2008. DOI= http://www2.camara.leg.br/legin/fed/lei/2008/lei-1177117-setembro-2008-580751-publicacaooriginal-103604-pl.html

BRASIL. 2007. Ministério do Turismo. Secretaria Nacional de Políticas de Turismo. Departamento de Estruturação, Articulação e Ordenamento Turístico Coordenação Geral de Regionalização. Roteiros do Brasil. Programa de Regionalização do Turismo. Conteúdo fundamental: Turismo e sustentabilidade

BRASIL. 2002. Lei $n^{\circ}$ 9.795, de 27 de abril de 1999. Dispõe sobre a educação ambiental, institui a Política Nacional de Educação Ambiental. Diário Oficial da União. Brasília, DF, 26 jun. 2002. DOI= http://www2.camara.leg.br/legin/fed/de cret/2002/decreto-4281-25-junho-2002-459149-publicacaooriginal-1-pe.html

BRASIL. 1981. Lei $\mathrm{n}^{\circ}$ 6.938, de 31 de agosto de 1981. Dispõe sobre a Política Nacional do Meio Ambiente, seus fins e mecanismos de formulação e aplicação, e dá outras providências. Diário Oficial da União. Brasília, DF, 02 set. 1981. DOI= http://www2.camara.leg.br/legin/fed/lei/1980-1987/lei-6938-31-agosto-19 $\underline{\text { 81-366135-normaatualizada-pl.pdf }}$

Cirilo, L. 2005. O turismo e a educação ambiental: um processo de saber/aprender e aprender/fazer comunitários. Revista Global Tourism - Turismo e Educação, São Paulo, v.1, n.2, nov.

Denker, A. F. M. 1998. Métodos e técnicas de pesquisa em turismo. São Paulo: Futura. 
Hillel, O. 1999. Turismo ambiental: uma jornada de conhecimento. In: Camargo, $L$. O. L. (Org.). Perspectivas e resultados de pesquisa em educação ambiental. São Paulo: Arte \& Ciência.

Marconi, M. A. e Lakatos, E. M. 2006. Técnicas de pesquisa. São Paulo: Atlas.

Mendonça, R. 2001. Turismo ou meio ambiente: uma falsa oposição? In: Lemos, A. I. G. de. Turismo: impactos socioambientais. 3 ed. São Paulo: Hucitec.

Oliveira, A. P. 2000. Turismo e desenvolvimento: planejamento e organização. São Paulo: Atlas.

Oliveira, E. S. 2008. Impactos ambientais e econômicos do turismo e suas repercussões no desenvolvimento local: o caso de Itacaré-Bahia. Dissertação (Mestrado em Cultura e Turismo) - Universidade Estadual de Santa Cruz/ Universidade Federal da Bahia, Ilhéus. DOI=http://www.uesc.br/cursos/pos_g raduacao/mestrado/turismo/dissertacao/mono_elton_silva.pdf.

Oliveira, L. F. e Irving, M. A. 2010. Ecoturismo no Parque Estadual da Ilha Grande: interpretando o turismo a partir do olhar local. In: XI Encontro Nacional de Turismo com Base Local. Niterói, p.878 - 900.

Quintas, J. S. 2000. Por uma educação ambiental emancipatória: considerações sobre a formação do educador para atuar no processo de gestão ambiental. In: Quintas, $J$. S. (Org.). Pensando e praticando a educação ambiental na gestão do meio ambiente. Brasília: IBAMA.

Ruschmann, D. V. M. 1997. Turismo e planejamento sustentável: a proteção do meio ambiente. Campinas, SP: Papirus.

Silva, J. A. 2004. Direito ambiental constitucional. $5^{\text {a }}$. ed. São Paulo: Malheiros.

World Tourism Organization - UNWTO. 2013. Sustainable Tourism for development Guidebook. First edition. Madrid (Spain).

World Tourism Organization - UNWTO. 2015. United Nations declares 2017 as the International Yer of Sustainable Tourism for Development. Press Release. DOI= http://media.unwto.org/press-release/2015-12-07/united-nations-declares-2017international-year-sustainable-tourism-develop 